\title{
Factors affecting green food purchase intention in Ho Chi Minh City
}

\author{
Nguyen Thi Thanh $\operatorname{Van}^{1 *}$, Nguyen Thien Duy ${ }^{2}$, Pham Tien Dung ${ }^{2}$ \\ ${ }^{1}$ Ho Chi Minh City University of Technology and Education, Vietnam \\ ${ }^{2}$ The University of Economics Ho Chi Minh City, Vietnam \\ *Corresponding author: vanntt@hcmute.edu.vn
}

\begin{tabular}{ll}
\hline \multicolumn{1}{c}{ ARTICLE INFO } & \multicolumn{1}{c}{ ABSTRACT } \\
\hline $\begin{array}{l}\text { DOI:10.46223/HCMCOUJS. } \\
\text { econ.en.8.1.172.2018 }\end{array}$ & $\begin{array}{l}\text { This study adopts Theory of Planned Behavior (TPB) and } \\
\text { Technology Acceptance Model (TAM) to measure factors } \\
\text { affecting green food purchase intention in Ho Chi Minh city } \\
\text { (HCMC). The survey data was collected from 197 students } \\
\text { during the period of } 1^{\text {st }} \text { to } 20^{\text {th }} \text { September, 2017. Testing the } \\
\text { conceptual model by Structural Equation Modeling (SEM), we } \\
\text { Received: October } 1^{\text {st }}, 2017\end{array}$ \\
Revised: November $19^{\text {th }}, 2017$ & $\begin{array}{l}\text { find that perceived usefulness of green food and perceived ease } \\
\text { of purchase impact on attitudes towards green food purchase. } \\
\text { We also find that subjective norm, perceived usefulness of } \\
\text { green food, attitudes towards green food purchase are }\end{array}$ \\
Keywords: & $\begin{array}{l}\text { positively associated with green food purchase intention. From } \\
\text { green food, purchase intention, } \\
\text { the research findings, some recommendations are proposed } \\
\text { accordingly. }\end{array}$ \\
\hline
\end{tabular}

\section{Introduction}

Environmental protection has become a matter of concern to many individuals, organizations and nations when the environment is increasingly threatened. It is the awareness of the environmental issue that leads to a significant change in people's purchase and production intentions. Especially in the aspect of purchase intention, environmentalists assess green purchase as an important solution to the protection of the environment and human beings (Hoang, 2017). The green purchase has become popular in developed nations and developing ones. In Vietnam, it is a relatively new concept that has not caught much public attention.

Ho Chi Minh City is the largest food market where most consumers are still reluctant to use green food. According to a survey conducted in HCMC by University of Technology in 2016, the main reason for this reluctance is economic hardship and lack of green purchase habits. Owing to this fact, manufacturers often attach more attention to price than quality and food safety. For instance, the amount of chemical residues in many kinds of food is used over the limits in order to increase productivity; poor-quality materials for farming and breeding are chosen to reduce costs; most food cannot be found out about their sources. Therefore, if consumers have a change in their attitudes towards green food, it will also stimulate producers to change their way of production to meet their needs. Bhatt and Bhatt (2015) also argued that $30 \%$ to $40 \%$ of 
environmental degradation comes from household consumption. Consumers' purchase behavior is considered as a significant subject when manufacturers produce new products. Therefore, if consumers favor environmentally - friendly products, firms will accordingly change their production methods, thus contribute to environmental protection. Besides, at present manufacturers have considerable difficulty in determining food quality so it is the reason why consumers disbelieve in green food, and green food manufacturers suffer hardships in the face of competition. In the light of this analysis, identifying factors that impact on green food purchase intention in HCMC is crucial to help green food producers understand and adjust their activities to satisfy consumer needs, thus gradually promote green food purchase intention.

Many studies focused on understanding purchase intention in a variety of products. For example, Barber, Kuo, Bishop, and Goodman (2012) explained the purchase intention in wine product, Sentosa and Mat (2012) examined intention and internet purchase behavior, Ziadat (2015) researched on tourism services, Vuong and Trinh (2017) studied consumer intention of using credit cards, etc.

Researching green products is a matter of greatest importance when people become more aware of health and the environment. Khan, Chamhuri and Farah (2015) reviewed 9 papers concerning green food consumption in Malaysia and revealed that the majority of Malaysians consider food safety and health issue as their prime reason for buying green food. Tan (2013) predicted the intention of purchasing green and sustainable homes. Pastiu (2013) examined the green purchase intention of Romanian consumers. In Vietnam context, some researchers studied the purchase intention of food safety such as K. T. Nguyen and A. T. L. Nguyen (2016); Le (2014); P. T. Nguyen (2011); Truong, Yap, and Ineson (2012).

Most of the studies about purchase intention use TPB and TAM as two prominent theoretical approaches, but we recognize that it is better to use only TPB as the background theory for analyzing the green food purchase intention than to use TAM in this case. In our opinion, green food is significantly different from conventional food. Especially in HCMC, green food is not popular so it cannot be easily bought in the traditional market, thus we think that 'perceived ease to buy' and 'perceived usefulness' can impact the purchase intention. As Rezaei, Javad, and Javad (2012) suggested, TAM can also be established as a robust economic model for the prediction of adoption. Therefore, the purpose of this paper is to combine TPB and TAM in the green food purchase intention which has rarely been applied for green products and has not yet been studied in Vietnam.

\section{Theoretical background and proposed research model}

\section{Green purchase intention}

Chan (2011) said that green purchasing refers to the purchase of environmentally friendly products and avoiding harmful ones. Green purchasing includes two stages: intention and behavior. In this paper, we focus on the former because the best predictor of purchase behavior is customers' intention.

Ramayah, Lee, and Mohamad (2010) defined green purchase intention as consumers' willingness to purchase green products. Arshad, Madmood, Siddiqui, and Tahir (2014) defined 
it as an intention to buy a service or product which does little or no harm to the society and environment. According to Ottman (1992), consumers purchase green products when they realize that green products can help to solve the environmental problem, food safety issues, animal welfare and they are healthy to consume.

\section{Green food}

In recent years, conventional food has developed rapidly and has been considered as the main cause of public health hazards (Williams \& Hammitt, 2001). The customers have become worried about what they eat. The demand for healthy eating patterns has raised, for this reason, green food is the preferable choice for customers. Green food refers to one that is safe to be consumed, of fine quality, nutritious, concerned with animal welfare and it is produced under the principle of sustainable development (Khan et al., 2015).

\section{Theory of Planned Behavior (TPB)}

The Theory of Planned Behavior (TPB) was proposed by Ajzen in 1985, developed from the theory of reasoned action (TRA) of Ajzen and Fishbein in 1980. According to TPB (Ajzen, 1985), if people evaluate the suggested behavior as positive (attitudes), and if they think that their significant people want them to perform the behavior (subjective norm), this results in a higher intention (motivations) and they are more likely to do so. TPB also suggests that people are much more likely to intend to perform behaviors when they feel that they can do them successfully. Thus, attitudes towards behavior, subjective norms, and perceived behavior control impact on purchasing intention.

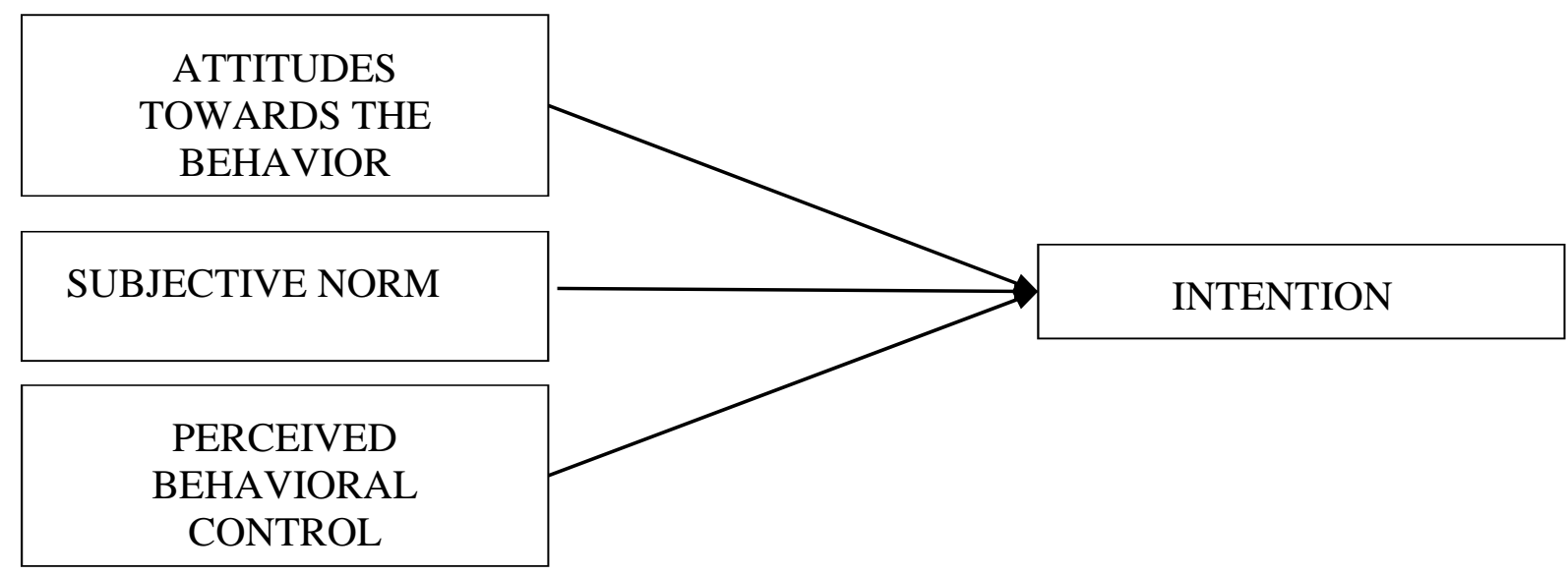

Figure 1. Theory of Planned Behavior (TPB) (based on Ajzen, 1985, 1991)

This correlation has been confirmed in many empirical studies. In the context of green foods, we can explain these concepts as follow:

Attitudes are one of the explanatory factors in the prediction of consumers' willingness to pay for green foods (Tsen, Phang, Hasan, \& Buncha, 2006). Attitudes refer to how consumers consider green food purchases as well as benefits and impacts obtained from this action (R. Wang, 2009). Squires, Juric and Cornwell (2001) thought that individuals who hold positive and favorable attitudes tend to purchase more green products than those without these attitudes. 
The relationship between attitudes and green purchase intention is also confirmed in many studies (Bhatt \& Bhatt, 2015; Tan, 2013; Teng, Rezai, Mohamed, \& Shamsudin, 2011).

Subjective norm is an individual's perception of the particular behavior, which is influenced by the judgment of significant people (e.g., parents, spouse, friends, teachers). If consumers believe that significant people think that green products are good, consumers will have more intention to buy these products (Kim \& Chung, 2011). Some studies also found that subjective norm has a positive correlation with the purchase intention of green products (Bhatt \& Bhatt, 2015; Tan, 2013; Teng et al., 2011).

Perceived Behavioral Control is the perceived control one has over one's actions. It refers to the capacity of an individual to perform a given behavior (Ajzen, 1988), to the individual's perception of the extent to which performance of the behavior is easy or difficult (Ajzen, 1991). Perceived behavioral control increases when people have more resources and confidence. Some studies found that perceived behavioral control has a significant and positive impact on purchase intention of green products (Tan, 2013; Teng et al., 2011; P. Wang, Liu, \& Qi, 2014).

\section{Technology Acceptance Model (TAM)}

TAM was developed by Davis, Bagozzi, and Warshaw, in 1989 and it is one of the most influential extensions of TPB in the literature. This model suggests that when users are presented with new technology, some factors - perceived ease of use; perceived usefulness influence their intention about how and when they use it.

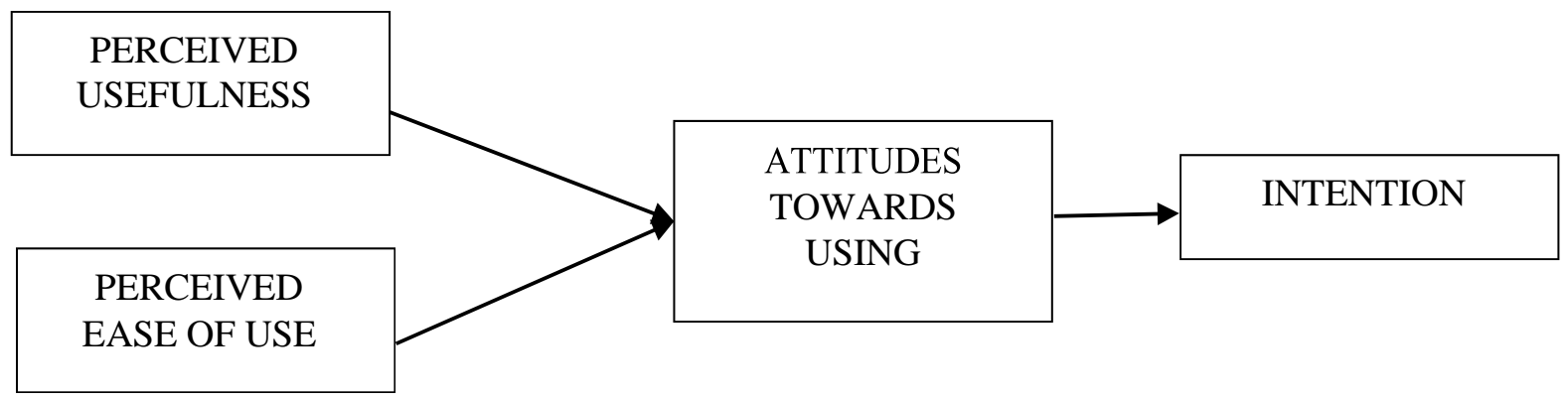

Figure 2. Technology Acceptance Model (TAM) (based on Davis et al., 1989)

Perceived Usefulness is defined as a person who believes that using a particular system will enhance his or her job performance (Davis et al., 1989).

Perceived Ease of Use is defined as an individual who believes the use of technology will be easy for him/her (Davis et al., 1989).

Some researches provided evidence of the significant effect of perceived usefulness and perceived ease of use on attitudes towards using (Juniwati, 2014; Renny, Guritno, \& Siringoringo, 2013) and usage intention (Celik, 2008; T. D. Nguyen, 2007; Sentosa \& Mat, 2012; Venkatesh \& Davis, 2000).

These correlations have been confirmed in many empirical studies. Although we have not yet found any researches that apply TAM to green food (product), we believe that TAM is 
a suitable model for this case study. In Vietnam, green food is not popular and easy to buy in the traditional markets. In order to be successful, green product developers need to have a clear understanding of whether perceived usefulness and perceived ease of use influence consumers' acceptance. Besides, this predictive capability of TAM does not always hold in cases that the use of technology in a specific field is considered (Jokar, Noorhosseinia, Allahyarib, \& Damalas, 2017). The TAM has been established as a robust economic model for the prediction of adoption in the last few years (Rezaei et al., 2012; Venkatesh \& Davis, 2000). Jokar et al. (2017) used TAM to explore the consumers' acceptance of medicinal herbs. Understanding generic variables used in the TAM would allow proper manipulation towards promoting green product acceptance and consumption. Thus, this study suggests the perceived usefulness of green food and perceived ease of purchase impact on attitudes towards green food purchase, which subsequently influences green purchase intention.

Based on TPB, TAM and above-mentioned researches, we can make hypothesis:

H1: Perceived usefulness of green food has a positive impact on attitudes towards purchase green food

H2: Perceived ease of purchase has a positive impact on attitudes towards purchase green food

H3: Perceived usefulness of green food has a positive impact on green food purchase intention

H4: Perceived ease of purchase has a positive impact on green food purchase intention

H5: Attitudes towards green food purchase has a positive impact on green food purchase intention

H6: Subjective norm has a positive impact on green food purchase intention

H7: Perceived behavioral control has a positive impact on green food purchase intention

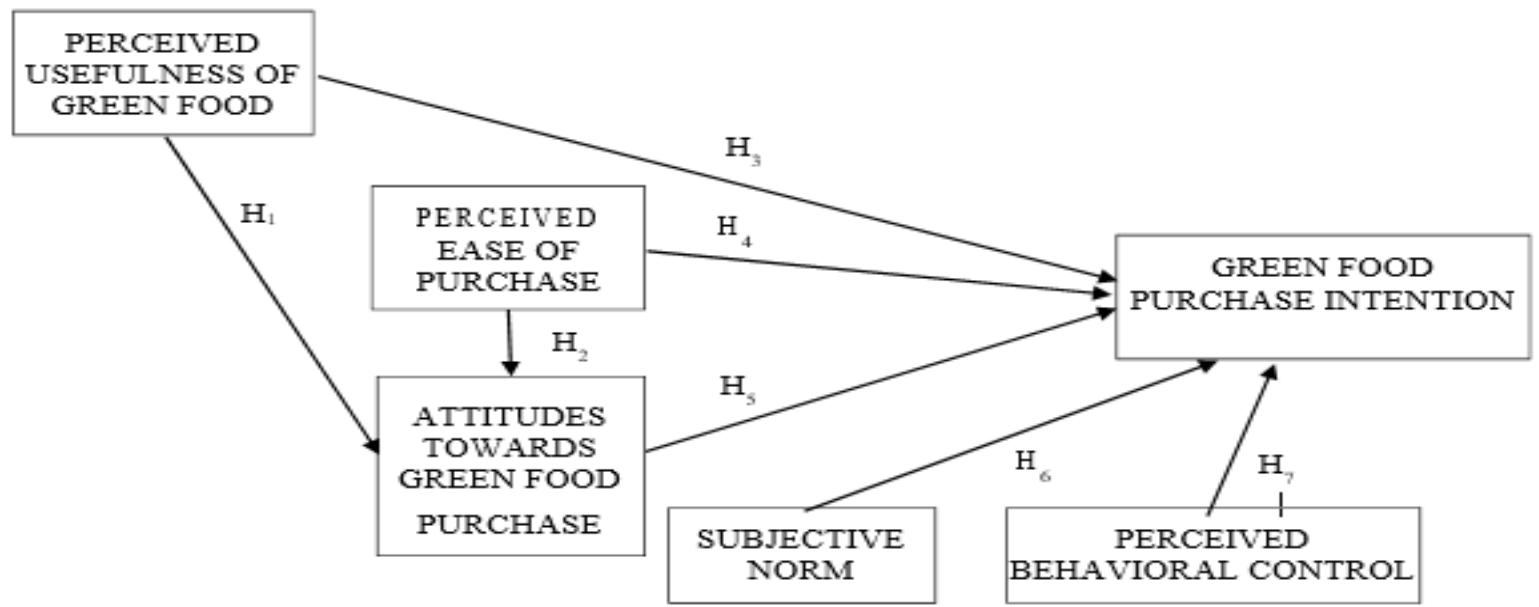

Figure 3. Research model 


\section{Research methodology}

\section{The respondent}

The more aware humans are of environmental issues, the more they can foresee the consequences which are caused by their purchase behavior, therefore, they change their understanding and purchase intention (K. T. Nguyen \& A. T. L. Nguyen, 2016). Moreover, according to the survey conducted by HCMC University of Technology in 2016, young single people with high education are willing to pay more than $1 \%$ to $10 \%$ of the price to buy green products. They have an adequate understanding of green products and open-minded attitudes. Besides, marketing specialists are often turning to the younger generation with promotional campaigns. Last but not least, educating the young generation on green products should be a top priority.

For this purpose, a quantitative survey was conducted with personal interviews. The researchers explained the questionnaires to the students in the classroom. The sampling method adopted is convenience sampling. Bollen (1989) suggested that an empirical ratio of at least five observations per each estimated parameter (5:1). Thus, a sample size of 100 (20x5) or more can be accepted for this research.

A total of 400 questionnaires were delivered during the period of $1^{\text {st }}$ to $20^{\text {th }}$ September 2017, and 197 ones with completed information were used in the analysis. Descriptive statistics were performed to know the general socio-demographic characteristics of the respondents in this survey. Table 1 shows that 135 female respondents were interviewed, which are twice as many as male ones. In terms of academic year, sophomores account for 38.6 percent, juniors and freshmen account for 27.9 percent and 23.9 percent respectively, while seniors account for 9.6 percent. In terms of income, it is noticeable that the majority of respondents come from middle class, while the others come from the working class, upper-middle-class and upper class respectively. About source of income, agriculture is a major source of income, most respondents' families receive their income from the sale of agricultural products then employment and private business are the other sources of income.

\section{Table 1}

Demographic characteristics of the sample

\begin{tabular}{lcc}
\hline Particular & Frequency & Percentage \\
\hline - Gender & & \\
Male & 62 & 31.5 \\
Female & 135 & 68.5 \\
- Educational year & & \\
First year & 47 & 23.9 \\
Second year & 76 & 38.6 \\
Third year & 55 & 27.9 \\
Fourth year & 19 & 9.6 \\
- Income & &
\end{tabular}




\begin{tabular}{lcc}
\hline Particular & Frequency & Percentage \\
\hline Upper Class & 6 & 3 \\
Upper Middle Class & 8 & 4.1 \\
Middle Class & 169 & 85.8 \\
Working Class & 14 & 7.1 \\
- Main Income & & \\
Agriculture & 82 & 41.6 \\
Private Business & 50 & 25.4 \\
Employment & 65 & 33.0 \\
\hline
\end{tabular}

Source: The researcher's data analysis

\section{Methods}

The data were analyzed by AMOS software, which is also applied to test the research hypotheses. For the measurement quality, confirmatory factor analysis (CFA) was conducted to assign variables to manifest a construct by determining the reliability and validity of the items used. SEM analysis with AMOS was used to estimate the measurement and structural model for quality and fit.

\section{Measurement Variables}

The measurement items were adapted and evaluated from previous studies, namely Sentosa and Mat (2012), Tan (2013). In addition, a 7-point Likert scale was used, ranging from strongly disagree (1) to strongly agree (7).

\section{Data analysis and results}

\subsection{Testing for reliability of the scales}

Before testing the hypotheses, we initially test the measurement items for each of the constructs in the model via Cronbach's alpha. In Table 2, the Cronbach's alphas of all scales are rather high (the minimum of Cronbach's alpha is 0.726 ), and the item-total correlations of all items are also high (the minimum is 0.473 ). Thus, all measurement items should be tested using Exploratory Factor Analysis (EFA).

\section{Table 2}

Cronbach's Alpha results of measurement items

Code Construct

Attitudes Towards Purchase Green Food (AT)

AT1 I am willing to purchase green food

AT2 Purchasing green food is an idea I like

AT3 I feel that green food purchasing gives me inspiration Subjective Norm (SN)
Cronbach's Alpha

0.726

0.540

0.650

0.473

0.834

0.682

SN1 Most members of my family would expect me to purchase green food 


\section{Code Construct}

Cronbach's Alpha

SN2 I intend to follow the advice of my family and friends that I should purchase green food

SN3 It is expected of me that I will purchase green food in the forthcoming

0.672 month

SN4 My family and friends would recommend that I should purchase green food

\section{Perceived Behavioral Control (PBC)}

0.615

PBC1 I am capable of purchasing green food

0.751

$\mathrm{PBC} 2$ Purchasing green food is entirely within my control

0.551

$\mathrm{PBC} 3$ It is easy to purchase green food

\section{Perceived Usefulness of Green Food (PU)}

PU1 Purchasing green food helps improve my health

PU2 Purchasing green food helps improve unsafe food problems

PU3 I find the purchasing green food useful

0.683

PU4 I think that green food purchasing helps protect the environment

\section{Perceived Ease of Purchase (PE)}

PE1 Purchasing green food is easy

PE2 There are a lot of green food stores where easy to come

PE3 The transactions of purchasing green food are fast

0.765

Green Food Purchase Intention (PI)

PI1 If there are a lot types of green foods, I will purchase them

PI2 I will try to purchase green food in the future

PI3 I intend to purchase green food as much as possible

Source: Data analysis result of the research

Exploratory Factor Analysis (EFA) with principal axis factoring in conjunction with promax rotation was conducted to explore the dimensionality of factors (construct). The results shown in Table 3 indicate that the minimum of KMO index is 0.629 , that of eigenvalues is 1.525 , and that of total variance explained (TVE) is $50.548 \%$.

\section{Table 3}

EFA results of measurement items

\begin{tabular}{|c|c|c|c|c|}
\hline Factor & KMO & $\begin{array}{c}\text { Number } \\
\text { of items }\end{array}$ & Eigen-value & $\begin{array}{c}\text { Total } \\
\text { variance } \\
\text { explained }\end{array}$ \\
\hline Attitudes towards purchase green food & $\begin{array}{c}0.629 \\
(\mathrm{Sig}=0.000)\end{array}$ & 3 & 1.942 & 50.548 \\
\hline Subjective norm & \multirow{2}{*}{$\begin{array}{c}0.785 \\
(\mathrm{Sig}=0.000)\end{array}$} & 4 & \multirow{2}{*}{1.525} & \multirow{2}{*}{54.301} \\
\hline Perceived behavioral control & & 3 & & \\
\hline Perceived usefulness of green food & \multirow{2}{*}{$\begin{array}{c}0.786 \\
(\mathrm{Sig}=0.000)\end{array}$} & 4 & \multirow{2}{*}{1.874} & \multirow{2}{*}{63.464} \\
\hline Perceived ease to purchase & & 3 & & \\
\hline
\end{tabular}




\begin{tabular}{|c|c|c|c|c|}
\hline Factor & KMO & $\begin{array}{c}\text { Number } \\
\text { of items }\end{array}$ & Eigen-value & $\begin{array}{c}\text { Total } \\
\text { variance } \\
\text { explained }\end{array}$ \\
\hline Green food purchase intention & $\begin{array}{c}0.726 \\
(\mathrm{Sig}=0.000)\end{array}$ & 3 & 2.316 & 66.023 \\
\hline
\end{tabular}

Source: Data analysis result of the research

The reliability analysis results reveal that these scales receive acceptable Cronbach's alpha (CRA $>0.6)$, and that item-total correlations are relatively high compared to the acceptable level $(>0.3)$. The results of exploratory factor analysis also show that the dimensions proposed for each construct have been demonstrated to be reasonable (KMO >0.5; eigenvalues $>1$; and total variance explained >0.5) (Hair, 1998).

\subsection{Results of Confirmatory Factor Analysis (CFA)}

The results of CFA of the measurement model indicate that the model fits the data well in this case study, including Chi-square $=300.062, \mathrm{df}=150, \mathrm{GFI}=0.876(>0.8)$; TLI $=0.908$ and CFI $=0.928(>0.9)$, Chi-square/df $=2.000$ and RMSEA $=0.071(<0.8)$. Furthermore, all of the weighted CFA of the observed variables are higher than 0.5 , which ensures the convergent validity of the scales (Hair, 1998).

The correlations between constructs together with their p-value indicate that they are significantly different from unity (Table 4). The findings support the across-construct discriminant validity.

\section{Table 4}

Correlations between constructs

\begin{tabular}{|c|c|c|c|}
\hline Correlation & $\mathbf{R}$ & P-value & Conclusion \\
\hline $\mathrm{AT} \leftrightarrow \mathrm{PU}$ & 0.529 & 0.0000 & Discriminant \\
\hline $\mathrm{AT} \Leftrightarrow \mathrm{PE}$ & 0.332 & 0.0000 & Discriminant \\
\hline $\mathrm{PI} \Longleftrightarrow \mathrm{SN}$ & 0.763 & 0.0000 & Discriminant \\
\hline $\mathrm{PI} \longleftrightarrow \mathrm{PBC}$ & 0.375 & 0.0000 & Discriminant \\
\hline $\mathrm{PI} \longleftrightarrow \mathrm{PU}$ & 0.654 & 0.0000 & Discriminant \\
\hline $\mathrm{PI} \longleftrightarrow \mathrm{PE}$ & 0.142 & 0.0460 & Discriminant \\
\hline $\mathrm{PI} \longleftrightarrow \mathrm{AT}$ & 0.731 & 0.0000 & Discriminant \\
\hline
\end{tabular}

Source: Data analysis result of the research

Then, we tested the composite reliability coefficients and Average Variance Extracted (AVE) for each construct. The results are provided in Table 5. All of the composite reliability 
coefficients are higher than $50 \%$ (the minimum is $73.75 \%$ ). Besides, all of the AVE values are higher than $50 \%$ (the minimum is $50.76 \%$ ).

Generally, the CFA results were adapted with all requirements. Combine with the results of CRA and EFA above, it can be confirmed that all of the scales and constructs employed in this paper are reliable.

\section{Table 5}

Results of composite reliability coefficients and average variance extracted

\begin{tabular}{|c|c|c|c|}
\hline & $\mathbf{N}$ & Composite Reliability Coefficients $\left(\rho_{c}\right)$ & Average Variance Extracted $\left(\rho_{\mathrm{vc}}\right)$ \\
\hline PI & 197 & $85.37 \%$ & $66.07 \%$ \\
\hline AT & 197 & $73.75 \%$ & $58.51 \%$ \\
\hline SN & 197 & $83.64 \%$ & $56.12 \%$ \\
\hline PBC & 197 & $75.46 \%$ & $50.76 \%$ \\
\hline PU & 197 & $84.97 \%$ & $58.79 \%$ \\
\hline PE & 197 & $85.65 \%$ & $66.58 \%$ \\
\hline
\end{tabular}

Source: Data analysis result of the research

\subsection{Testing the research model via Structural Equation Modelling (SEM)}

The results of SEM with Chi-square $=301.078, \mathrm{GFI}=0.882(>0.8)$; TLI $=0.916, \mathrm{CFI}$ $=0.934(>0.9)$, RMSEA $=0.069(<0.8)$ and Chi-square/df $=2.002$, indicate that the model fits the data well in this case study. Measurement quality the hypothesis is shown in Table 6.

\section{Table 6}

Structural results (unstandardized estimates)

\begin{tabular}{|c|c|c|c|c|c|c|c|c|}
\hline & & & $\begin{array}{c}\text { Unstandardized } \\
\text { Regression } \\
\text { Weights }\end{array}$ & $\begin{array}{c}\text { Standardized } \\
\text { Regression } \\
\text { Weights }\end{array}$ & Critical & P-value & Hypothesis & $\begin{array}{c}\text { Hypothesis } \\
\text { support }\end{array}$ \\
\hline $\mathrm{AT}$ & $\leftarrow$ & PU & 0.614 & 0.700 & 7.026 & 0.000 & H1 & Yes \\
\hline $\mathrm{AT}$ & $\leftarrow$ & $\mathrm{PE}$ & 0.123 & 0.189 & 2.338 & 0.019 & $\mathrm{H} 2$ & Yes \\
\hline PI & $\leftarrow$ & $\mathrm{SN}$ & 0.392 & 0.387 & 3.719 & 0.000 & H6 & Yes \\
\hline PI & $\leftarrow$ & PBC & 0.07 & 0.096 & 0.908 & 0.364 & $\mathrm{H} 7$ & No \\
\hline PI & $\leftarrow$ & PU & 0.242 & 0.259 & 2.004 & 0.045 & $\mathrm{H} 3$ & Yes \\
\hline PI & $\leftarrow$ & $\mathrm{PE}$ & -0.107 & -0.154 & -1.638 & 0.101 & $\mathrm{H} 4$ & No \\
\hline PI & $\leftarrow$ & $\mathrm{AT}$ & 0.292 & 0.274 & 2.737 & 0.006 & H5 & Yes \\
\hline
\end{tabular}

Source: Data analysis result of the research 
H1 examines the relationship between perceived usefulness of green food and attitudes towards green food purchase, which is supported with standardized regression weights $=0.7$, $\mathrm{CR}=7.026$ and $\mathrm{p}=0.000$. Perceived usefulness of green food was also found to have a positive impact on green food purchase intention - H3 is supported with standardized regression weights $=0.259, \mathrm{CR}=2.004$ and $\mathrm{p}=0.045 \mathrm{H} 2$ is supported with standardized regression weights $=$ $0.189, \mathrm{CR}=2.338$ and $\mathrm{p}=0.019$, suggesting that perceived ease of purchase is also a significant driver of attitudes towards green food purchase. H6 examines the relationship between subjective norm and green food purchase intention, which is supported with standardized regression weights $=0.387, \mathrm{CR}=3.719$ and $\mathrm{p}=0.000$. Attitudes towards purchase green food were also found to have a positive impact on green food purchase intention - H5 is supported (standardized regression weights $=0.274, \mathrm{CR}=2.737$ and $\mathrm{p}=0.006$ ).

\section{Conclusion and implications}

\subsection{Discussion of results and implications}

Based on concepts and paths of TAM as well as previous empirical studies (Juniwati, 2014; Renny et al., 2013), this paper shows that the positive relationship between perceived usefulness of green food (H1); perceived ease of purchase (H2) and attitudes towards purchase green food. When students realize that buying green food is easy and it improves their health, they are willing to buy it.

This support H3 indicates that the more perceived usefulness the students get, the more likely they are to green food purchase intention. This finding is consistent to that of Jokar et al. (2017), which found that whenever consumers use medicinal herbs which can provide healthiness and eating quality, they will be willing to purchase and use them.

These are a meaningful matter to green food manufacturers. If they want to enhance students' green food purchase intention, they need to increase communication, thus students are aware of the benefits of green food. Manufacturers should clearly announce the ingredients, functions of the green product, as well as commit to consumers that product is consistent with what they have informed. Manufacturers should pay attention to the distribution channels so that students can easily purchase green food.

TPB is also useful in this study. Specifically, these hypothesized relationships between subjective norms (H6); attitudes toward buying green food (H5) and green food purchase intention are also supported. This result is consistent with those of Bhatt and Bhatt (2015); Tan (2013); Teng et al. (2011). They imply that parents, friends, teachers, etc. could have an influence on students' green food purchase intention and students' favorable attitudes towards preferences and purchase. From here, the manufacturer is recommended not only to focus on target customers (students) but also need to pay attention to their significant people, who often give students advice on green consumption.

\subsection{Conclusion}

Green food is still a new concept in Vietnam but it will become more popular when Vietnamese consumers pay more attention to their health and environment. This study 
constructs hypothesized model by integrating TPB and TAM to test these factors which impact on green food purchase intention. Some hypotheses are supported (1) both perceived usefulness of green food (PU) and perceived ease of purchase (PE) have a positive impact on attitudes towards purchase green food (AT). Thus, attitudes towards green food purchase (AT) positively influence green food purchase intention (PI). This means that these factors have an indirect effect on green food purchase intention through attitudes towards purchase green food; (2) perceived usefulness of green food (PU) has a direct positive impact on green food purchase intention (PI); (3) Subjective norm (SN) has a positive impact on green food purchase intention (PI). These show that TPB and TAM can be used as the economic model for the prediction of green food purchase intention.

\section{References}

Ajzen, I. (1985). From intentions to actions: A theory of planned behavior. In J. Kuhl, \& J. Beckmann (Eds.), Action control: From cognition to behavior (pp. 11-39). Heidelberg, Berlin: Springer.

Ajzen, I. (1988). Attitudes, personality, and behavior. Chicago, IL: Dorsey Press.

Ajzen, I. (1991). The theory of planned behavior. Organizational Behavior and Human Decision Processes, 50(2), 179-211. doi:10.1016/0749-5978(91)90020-T

Ajzen, I., \& Fishbein, M. (1980). Understanding attitudes and predicting social behavior. Englewood Cliffs, NJ: Prentice-Hall.

Arshad, R., Madmood, U., Siddiqui, H., \& Tahir, A. (2014). An empirical study about green purchase intentions. Journal of Sociological Research, 5(1), 290-305. doi:10.5296/jsr.v5i1.6567

Barber, N., Kuo, P.-J., Bishop, M., \& Goodman, R. J. (2012). Measuring psychographics to assess purchase intention and willingness to pay. Journal of Consumer Marketing, 29(4), 280-292. doi:10.1108/07363761211237353

Bhatt, R., \& Bhatt, K. (2015). Analyzing psychographic factors affecting green purchase intention. Journal of Contemporary Research in Management, 10(1), 45-55.

Bollen, K. A. (1989). Structural equations with latent variables. Hoboken, NJ: John Wiley \& Son, Inc.

Celik, H. (2008). What determines Turkish customers' acceptance of internet banking? International Journal of Bank Marketing, 26(5), 353-370. doi:10.1108/02652320810894406

Chan, R. Y. K. (2001). Determinants of Chinese consumers' green purchase behavior. Psychology and Marketing, 18(4), 389-413. doi:10.1002/mar.1013

Davis, F. D., Bagozzi, R. P., \& Warshaw, P. R. (1989). User acceptance of computer technology: A comparison of two theoretical models. Management Science, 35(8), 9821003. doi:10.1287/mnsc.35.8.982 
Hair, A. (1998). Multivariable Data Analysis. Upper Saddle River, NJ: Prentice-Hall International, Inc.

Hoang, T. T. B. (2017). Nghiên cưu nhũng nhân tố tác động tới mối quan hệ giữa ý định và hành vi tiêu dùng xanh của người tiêu dùng Việt Nam [Study the factors affecting the relationship between Vietnamese consumers' green consumption intentions and behaviors] (Doctoral dissertation, VNU University of Economics \& Business, Vietnam). Retrieved March 20, 2016, from https://xemtailieu.com/tai-lieu/nghien-cuu-nhung-nhanto-tac-dong-toi-moi-quan-he-giua-y-dinh-va-hanh-vi-tieu-dung-xanh-cua-nguoi-tieudung-viet-nam-1412694.html

Jokar, N. K., Noorhosseinia, S. A., Allahyarib, M. S., \& Damalas, C. A. (2017). Consumers' acceptance of medicinal herbs: An application of the technology acceptance model (TAM). Journal of Ethnopharmacology, 207, 203-210. doi:10.1016/j.jep.2017.06.017

Juniwati (2014). Influence of perceived usefulness, ease of use, risk on attitude and intention to shop online. European Journal of Business and Management, 6(27), 218-228.

Kim, H. Y., \& Chung, J.-E. (2011). Consumer purchase intention for organic personal care products. Journal of Consumer Marketing, 28(1), 40-47. doi:10.1108/07363761111101930

Khan, M. R. T., Chamhuri, S., \& Farah, S. H. (2015). Green food consumption in Malaysia: A review of consumers' buying motives. International Food Research Journal, 22(1), 131138.

Le, H. T. (2014). Nghiên cứu các nhân tố ảnh hưởng đến ý định mua thực phẩm an toàn của cu dân đô thị - lấy ví du tại thành phố Hà Nội [Study of factors influencing urban residents' intention to buy safe food - take an example in Hanoi City] (Doctoral dissertation, National Economics University, Vietnam). Retrieved April 20, 2016, from https://www.slideshare.net/garmentspace/nghin-cu-cc-nhn-t-nh-hng-n-nh-mua-thc-phman-ton-ca-c-dn-th-ly-v-d-ti-thnh-ph-h-ni

Nguyen, K. T., \& Nguyen, A. T. L. (2016). Nghiên cứu ý định tiêu dùng xanh của người tiêu dùng tại Thành phố Hồ Chí Minh [Research consumer green consumption intentions in Ho Chi Minh City]. Tạp chí khoa học Đại học Mở TP. Hồ Chí Minh, 2(47), 42-53.

Nguyen, P. T. (2011). A comparative study of the intention to buy organic food between consumers in Northern and Southern Vietnam. Gsbjournal.au.edu, AU-GBS e-journal, $4(2), 102-113$.

Nguyen, T. D. (2007). Factors affecting the utilization of the internet by internationalizing firms in transition markets. Evidence from Vietnam. Marketing Intelligence \& Planning, 25(4), 360-376. doi:10.1108/02634500710754592

Ottman, J. (1992). Sometimes consumers will pay more to go green. Journal of International Consumer Marketing, 16, 12-120. 
Pastiu, C. A. (2013). Green purchase intentions of Romanian consumers. Annales Universitatis Apulensis Series Oeconomica, 15(2), 750-754. doi:10.29302/oeconomica.2013.15.2.39

Ramayah, T., Lee, J. W. C., \& Mohamad, O. (2010). Green product purchase intention: Some insights from a developing country. Resources, Conservation and Recycling, 54(12), 1419-1427. doi:10.1016/j.resconrec.2010.06.007

Renny, Guritno, S., \& Siringoringo, H. (2013). Perceived usefulness, ease of use, and attitude towards online shopping usefulness towards online airlines ticket purchase. Procedia Social and Behavioral Sciences, 81, 212-216. doi:10.1016/j.sbspro.2013.06.415

Rezaei, D. H., Javad, K. P., \& Javad, S. N. (2012). Investigating intention to e-shopping based on expansion of technology acceptance model. New Marketing Research Journal, 2(1), 93-110.

Sentosa, I., \& Mat, N. (2012). Examining a theory of planned behavior (TPB) and technology acceptance model (TAM) in internetpurchasing using structural equation modeling. Journal of Arts, Science \& Commerce, 3(2), 62-77.

Squires, L., Juric, B., \& Cornwell, T. B. (2001). Level of market development and intensity of organic food consumption: Cross-cultural study of Danish and New Zealand consumers. Journal of Consumer Marketing, 18(5), 392-409. doi:10.1108/07363760110398754

Tan, T. H. (2013). Use of structural equation modeling to predict the intention to purchase green and sustainable homes in Malaysia. Asian Social Science, 9(10), 181-191. doi:10.5539/ass.v9n10p181

Teng, P. K., Rezai, G., Mohamed, Z., \& Shamsudin, M. N. (2011). Consumers' intention to purchase green foods in Malaysia. 2011 International Conference on Innovation, Management and Service in Singapore, 14, 112-118.

Truong, T. T., Yap, M. H. T., \& Ineson, E. M. (2012). Potential Vietnamese consumer's perceptions of organic foods. British Food Journal, 114(4), 529-543. doi:10.1108/00070701211219540

Tsen, C.-H., Phang, G. I., Hasan, H., \& Buncha, M. R. (2006). Going green: A study of consumers' willingness to pay for green products in Kota Kinabalu. International Journal of Business and Society, 7(2), 40-54.

Venkatesh, V., \& Davis, F. D. (2000). A Theoretical Extension of the Technology Acceptance Model: Four Longitudinal Field Studies. Management Science, 46(2), 186-204. doi:10.1287/mnsc.46.2.186.11926

Vuong, Q. H. D., \& Trinh, N. H. (2017). Developing credit card market from Vietnamese consumers' perspective. Journal of Science Ho Chi Minh City Open University, 21(1).

Wang, R. (2009). Sustainable consumption from the consumer's perspective: A study on the purchase intentinon of green food in China (Master's thesis, University of Bedfordshire, England). $\quad$ Retrieved March 10, 2017, from https://uobrep.openrepository.com/bitstream/handle/10547/135334/Ruowei\%20Wang\% 20-\%20thesis\%201.pdf?sequence $=8 \&$ isAllowed $=y$ 
Wang, P., Liu, Q., \& Qi, Y. (2014). Factors influencing sustainable consumption behaviors: A survey of the rural residents in China. Journal of Cleaner Production, 63, 152-165. doi:10.1016/j.jclepro.2013.05.007

Williams, P. R. D., \& Hammitt, J. K. (2001). Perceived risks of conventional and organic product: Pesticides, pathogens and natural toxins. Risk Analysis, 21(2), 319-330. doi:10.1111/0272-4332.212114

Ziadat, M. A. (2015). Applications of planned behavior theory (TPB) in Jordanian tourism. International Journal of Marketing Studies, 7(3), 95-106. doi:10.5539/ijms.v7n3p95 